\title{
Effect of starch modification on physico-chemical, functional and structural characterization of cassava starch (Manihot esculenta Crantz)
}

\author{
${ }^{1}$ Dolas, K.A., ${ }^{2}$ Ranveer, R.C., ${ }^{3, *}$ Tapre, A.R., ${ }^{3}$ Nandane, A.S. and ${ }^{1}$ Sahoo, A.K. \\ ${ }^{1}$ Department of Technology (Food Tech), Shivaji University, Kolhapur, Maharashtra, India \\ ${ }^{2}$ PG Institute of Post Harvest Management, Killa- Roha, Dist. Raigad, Maharashtra, India \\ ${ }^{3}$ Department of Food Processing Technology, A.D. Patel Institute of Technology, New Vallabh, Vidyanagar, \\ Anand-388 121 Gujarat (India)
}

\begin{abstract}
Article history:
Received: 18 February 2020

Received in revised form: 19

March 2020

Accepted: 22 March 2020

Available Online: 14 April 2020
\end{abstract}

Keywords:

Cassava,

Starch modification,

Enzymatic modification,

Functional properties,

$\mathrm{X}$-ray diffraction

DOI:

DOI:
https://doi.org/10.26656/fr.2017.4(4).075

\section{Introduction}

Starch is the major reserve polysaccharide in plants and is in the form of granules that exist naturally within the plant cells. The important sources of food starch are corn, potato, wheat, cassava/tapioca and rice. Tapioca is a starch extracted from Cassava (Manihot esculenta, Crantz), of the family Euphorbiaceae, is an annual root crop that grows widely in tropical and sub-tropical areas. It is now grown widely as a food crop and for industrial purposes. Nowadays starch is not only used as a source of biological energy, but many foods and pharmaceuticals industries use starch or its derivatives in one form or another (Tester et al., 2004; Santana and Meireles, 2014). Starch can be used as a thickener, an adhesive, binder, encapsulating agent, film former, gelling agent, water binder, texturizer and fat-sparing agent and with numerous other applications both in the food and non-food areas (Mauro, 1996). At the industrial level, utilization of native starches was having various limitations due to their inability to withstand a very high temperature, diverse $\mathrm{pH}$ and high shear rate (Singh et al., 2007).

Also cooking and storage, particularly at low $\mathrm{pH}$, causes loss of viscosity, thickening power, syneresis tendency and retrograde. These limits their applications and industrial uses. To overcome these limitations of native starches and to improve the desired functional properties, native starches are often modified. Modification, (alteration of the physical and chemical characteristics to improve structural properties) can be used to improve inherent poor physico-chemical properties of native starch thus tailor it to the specific industrial application (Miyazaki et al., 2006).

Acid hydrolysis, oxidation, etherification, esterification and cross-linking methods can be used for starch modification. Various methods such as acid, phosphate and $\mathrm{H}_{2} \mathrm{O}_{2}$ treatments can be employed to modify starch (Akubor, 2007). The basic objective of starch modification is to alter the physico-chemical 
characteristics of native starch to improve functional characteristics viz. thickening, gelling, binding, adhesiveness and film-forming characteristics. The objective of this study was to evaluate the effect of chemical and enzymatic modification on physicochemical and functional properties of native cassava starch with their structural characterization Cassava is an important and cheap source of carbohydrate in tropical regions. Hence with the view, making it a potentially valuable food source for developing countries, cassava starch was used in the present investigation.

\section{Materials and methods}

Cassava root was purchased from a farmer market from Chera Dynasty, Kerala. The enzymes $\alpha$-Amylase extracted from malt obtained procured from Hi-Media Lab, Mumbai. Enzyme activity was 1:2000 I.P. Units. All the chemicals used in this investigation were of analytical grade

\subsection{Extraction of starch from cassava}

Fresh cassava tubers were washed, peeled, chopped and then pulverized in a high-speed blender for 5 mins. Cassava powder was then treated with $2 \% \mathrm{NaOH}$ solution with 1:5 proportion and kept $24 \mathrm{hrs}$ at room temperature. After $24 \mathrm{hrs}$ suspension was centrifuged to $10,000 \mathrm{rpm}$ for $10 \mathrm{mins}$. The precipitate thus obtained after centrifugation was washed with water and again centrifuged to get starch. This starch was then kept for drying at $40-45^{\circ} \mathrm{C}$ to get dried starch with $10 \%$ moisture content. This extracted starch was further used for modification.

\subsection{Starch modification}

There were two methods used for modification of extracted starch i.e. chemical and enzymatic modification.

\subsubsection{Chemical modification of starch by acetylated distarchadipate}

Native cassava starch was used to prepare $100 \mathrm{~g}$ proportion of a starch suspension in water with the concentration of $10 \mathrm{~g}$ starch per $100 \mathrm{~g}$ solution. The suspensions were heated to $70^{\circ} \mathrm{C}$ under continuous stirring till the moment of paste thickening that made starch sedimentation impossible. Afterwards, the suspension was left for $6 \mathrm{hrs}$ in a water bath at $94^{\circ} \mathrm{C}$ for complete starch pasting. The produced paste was left for $12 \mathrm{hrs}$ to cool at $20^{\circ} \mathrm{C}$. Next, it was frozen for three days at $-20^{\circ} \mathrm{C}$ and then defrosted for two days at $20^{\circ} \mathrm{C}$ till a temperature of $5^{\circ} \mathrm{C}$ has been reached. Precipitated starch with a spongy structure was rinsed with distilled water, dried at a temperature of $30^{\circ} \mathrm{C}$ for $24 \mathrm{hrs}$ followed by grinding and sieving (Kapelko-Zeberska et al., 2015). The preparation of retrograded starch was acetylated with $13 \%$ formic acid at $\mathrm{pH}$ 8.5. Afterwards, all produced preparation of acetylated retrograded starch was cross-linked with adipic acid at $\mathrm{pH}$ 9.0. The crosslinking was conducted to acetylation by dose of the cross -linking agent $2.0 \mathrm{~mL}$ per $100 \mathrm{~g}$ starch followed by drying at $30^{\circ} \mathrm{C}$. The cross-linking agent was prepared by hot dilution of $20 \mathrm{~g}$ of adipic acid in $80 \mathrm{~g}$ of formic acid (Zhong and Xia, 2008).

\subsubsection{Enzymatic modification of starch by $\alpha$-amylase enzyme}

Native cassava starch was modified using the $\alpha$ amylase enzyme as per the method followed by Kaper et al. (2005). The enzyme (16\%) was added to $100 \mathrm{~mL}$ native starch slurries in demineralized water supplemented with $271 \mathrm{ppm} \mathrm{CaCl}_{2}$. The starch-enzyme mixture was incubated at $100^{\circ} \mathrm{C}$ with constant shaking until gelatinization occurred (5 mins) and further incubated for $1 \mathrm{hr}$ at $100^{\circ} \mathrm{C}$. Next, incubation was continued at $80^{\circ} \mathrm{C}$ and after $1 \mathrm{hr}$, the samples were inactivated by autoclaving $\left(121^{\circ} \mathrm{C}, 30 \mathrm{mins}\right)$. The thermoreversible starch product (TSP) was purified by precipitation in $900 \mathrm{~mL} \mathrm{100 \%} \mathrm{ethanol} \mathrm{and} \mathrm{dried} \mathrm{on} \mathrm{a}$ paper filter at $32^{\circ} \mathrm{C}$ for $72 \mathrm{hrs}$. For determination of the dry matter content, $200 \mathrm{mg}$ of TSP was dried at $130^{\circ} \mathrm{C}$ for $2.5 \mathrm{hrs}$ and allowed to cool to room temperature in a bell jar with moisture-absorbing crystals for 30 mins. The dry matter content was calculated from the difference in weight before and after incubation.

\subsection{Proximate analysis}

Extracted native starch and modified starches were evaluated for physicochemical analysis such as moisture, protein, fat, ash, crude fiber and carbohydrates (Ranganna, 1987).

\subsection{Functional properties determination}

Cassava starch extracted was assessed for different functional properties as per standard procedure given below:

\subsubsection{Swelling power and solubility}

A solution of starch slurry (1\%) was made and heated in water-bath maintained at $90^{\circ} \mathrm{C}$ for 30 mins with constant stirring and cooled. The suspension was centrifuged at $3200 \mathrm{rpm}$ for $10 \mathrm{mins}$ and the supernatant (Upper layer) collected in a pre-weighed aluminum dish, which was evaporated at $110^{\circ} \mathrm{C}$ for $24 \mathrm{hrs}$. The dried aluminum dishes were weighed for calculation of solubility. The weight of wet sediment in the centrifuge tube was noted to determine the swelling power (Leach 
et al., 1959).

$$
\begin{aligned}
& \text { Swelling power }(\%)=\frac{(\text { Weight of swollen sediment) }}{\text { Weight of dry starch }} \times 100 \\
& \text { Solublity }(\%)=\frac{\text { (Weight of dry supernatant) }}{\text { Weight of dry starch }} \times 100
\end{aligned}
$$

\subsubsection{Water-binding capacity}

A suspension of $2.5 \mathrm{~g}$ native and treated sample in $20 \mathrm{~mL}$ of distilled water was agitated for 30 mins in a shaker (Narang Scientific Works, New Delhi, India). The suspension was poured into pre-weighed centrifuge tube. Then $10 \mathrm{~mL}$ of distilled water used for rinsing starch from the beaker, which was also added to the centrifuge tube and centrifuged at $3000 \mathrm{rpm}$ for $10 \mathrm{mins}$. The supernatant was decanted and wet starch was weighed to determine water-binding capacity (Anderson et al., 1969).

\subsection{Structural study}

Scanning electron micrographs were obtained with a scanning electron microscope (SEM) (Jeol JXA-840A, Jeol Ltd, Tokyo, Japan). Starch samples were applied on an aluminum stub using double-sided adhesive tape, and the starch was coated with gold (using auto quick gold coater). An acceleration potential of $15 \mathrm{kV}$ was used during micrography (Reddy and Bhotmange, 2013).

\subsection{Identification of starch}

\subsubsection{X-ray diffraction $(X R D)$}

The crystalline structure of the starches was analyzed by using a Philips X-ray diffractometer (MAC Science Co. MO3XHF22, Tokyo, Japan) at $35 \mathrm{kV}$ and $20 \mathrm{~mA} \mathrm{Cu}$ -Ka radiations. Diffractograms were obtained from $2^{\circ} \mathrm{C}$ to $35^{\circ} \mathrm{C}$ at a scan rate of $2 \% \mathrm{~min}$. In addition to as is samples, starches were hydrated with water and examined at 20 and $40 \%$ moisture content (Zhong and Xia, 2008).

\subsubsection{Fourier-transform infrared (FT-IR) spectroscopy}

FTIR spectra of unmodified and modified starches were obtained on FTIR spectrophotometer (Model \# Nicolet 5700, Thermo Electron Corporation, USA). The dry starch powders were used to record the spectra in the transmission mode from 4000 to $400 \mathrm{~cm}^{-1}$ wavenumber using deuterated tri-glycerine sulphate detector according to the method of Dupuy et al. (1997).

The evidence of esterification was verified by utilizing Fourier transfer infrared (FT-IR; Bomem MB Series) showing the shift of the carbonyl of carboxylic acid group to the carbonyl of ester group. For FT-IR spectroscopic analysis, the sample was ground, and the fine powder sample was mixed with dry potassium bromide. It was then made into a film that was analyzed in the beam of the FT-IR spectrophotometer (Rajan and Emilia, 2006.)

\subsection{Statistical analysis}

The analytical data obtained for experiments were subjected to analysis of variance (ANOVA) using complete randomized design according to Panse and Sukhatme (1989). The critical difference at $\mathrm{P}<0.05$ was estimated and used to find significant difference if any.

\section{Results and discussion}

\subsection{Effect of chemical and enzymatic modification on} proximate composition of starch

Proximate composition of native starch and chemically and enzymatic modified starch were determined, and comparative data are presented in Table 1. Both the modified starches were observed to have lower moisture, protein, fat as compared to native starch. The lower value was advantageous in terms of shelf life and keeping quality of the starches. The similar reducing trend of non-starch constituents in modified starches was reported by Olayinka et al. (2014) and Khatoon Sakina et al. (2009). This may be due to the increased purity of the modified starches.

\subsection{Effect of starch modification by different methods on functional properties}

Data depicted in Table 2 indicates that both chemically modified and enzymatic modified starches possessed higher water-binding capacity, i.e. $89.69 \%$ and $96.10 \%$ respectively than native starch with waterbinding capacity $70.63 \%$ The swelling power of chemically modified and enzymatic modified starches

Table 1. Effect of chemical and enzymatic starch modification on proximate composition of $\operatorname{starch}^{\mathrm{a}}$

\begin{tabular}{lccc}
\hline Constituents \% & Native Starch & Chemically modified starch & Enzymatic modified starch \\
\hline Moisture & $12.74 \pm 0.25$ & $10.09 \pm 0.01$ & $9.43 \pm 1.29$ \\
Protein & $0.8 \pm 0.14$ & $0.72 \pm 0.04$ & $0.64 \pm 0.3$ \\
Fat & $0.10 \pm 0.12$ & $0.9 \pm 0.03$ & $0.1 \pm 0.09$ \\
Ash & $0.1 \pm 0.01$ & $0.13 \pm 0.01$ & $0.09 \pm 0.11$ \\
Crude fiber & $0.15 \pm 0.2$ & $0.8 \pm 0.01$ & $0.13 \pm 0.08$ \\
Carbohydrate & $86.26 \pm 0.06$ & $88.16 \pm 0.05$ & $89.74 \pm 0.2$ \\
\hline
\end{tabular}

${ }^{\mathrm{a}}$ Each value represents the mean \pm standard deviation of three determinations 
Table 2. Effect of starch modification on functional properties of $\operatorname{starch}^{\mathrm{a}}$

\begin{tabular}{lccc}
\hline \multirow{2}{*}{ Functional property (\%) } & Native starch & Chemical Modification & Enzymatic Modification \\
\cline { 3 - 4 } & & $\begin{array}{c}(13 \% \text { acetic acid anhydride } \\
\text { concentration })\end{array}$ & $(16 \%$ Enzyme concentration $)$ \\
\hline Water-binding Capacity & $70.63 \pm 0.19$ & $89.69 \pm 0.24$ & $96.10 \pm 0.06$ \\
Swelling power & $22.56 \pm 0.36$ & $12.3 \pm 0.01$ & $8.70 \pm 0.03$ \\
Solubility & $25.18 \pm 0.45$ & $80.33 \pm 0.01$ & $79.66 \pm 0.04$ \\
\hline
\end{tabular}

${ }^{a}$ Each value represents the mean \pm standard deviation of three determinations

was observed to be $12.3 \%$ and $8.70 \%$ respectively which was lower as compared to native starch with swelling power $22.56 \%$. A similar trend was reported by Kaur et al. (2011). The reduction in swelling power of modified starches was reported due to increase in the high proportion of soluble dextrins of both small and mediumchain lengths in starch granules (John et al. 2002). Whereas modified starches observed to be highly soluble $(80.33 \%$ and $79.66 \%)$ compared to native starch with solubility $25.18 \%$. The acetylation increased solubility of cassava starch. This might be due to the presence of hydrophilic substituting groups that retain water (Betancur-Ancona et al., 2002). Following the introduction of acetyl groups on starch molecules, structural reorganization occurs as a result of steric hindrance and this result in repulsion, thus facilitating an increase in water penetration within the granules. Structural disintegration probably weakens the starch granules after modifications, and this enhanced leachates from the starch increased starch solubility. Similar observations have been reported earlier for starches of rice (Liu et al., 1999; Gonzalez and Perez, 2002), wheat (Wootton and Chaudhry, 1979) and great Northern Bean (Sathe et al., 1981).

\subsection{Structural analysis}

The morphology of the particles was imaged with a field emission scanning electron microscope (SEM). The SEM micrograph of native starch (NS) is presented in Figure 1(A). Native starch showed that the granules are round to polygonal in shape and similar to the structure was reported by French et al. (1984). The granule surface is relatively smooth and free from pores, cracks or fissures. Based on the observation, it shows that starch granules are polygonal in shape with sizes of about $10 \mu \mathrm{m}$. An acceleration potential of $20 \mathrm{kV}$ was used during micrography. The surfaces of starch granules are smooth.

The SEM micrograph of acetylated distarchadipate retrograded cassava starch is presented in Figure 1(B). Based on the observation, it shows that Acetylated distarchadipate retrograded starch significantly increased the granular size which could be due to the disruption of intragranular interactions which subsequently lead to size increment. Spherical, oval and spherical, and oval- shaped granules were observed with the size of about 10 $\mu \mathrm{m}$. in Acetylated distarchadipate retrograded starch. All modifications retained the granular structure of modified starch. Similar results are also reported by Das et al. (2010).
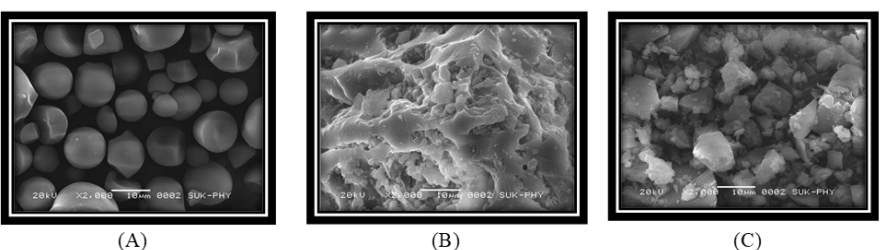

Figure 1. Scanning Electron Micoscope image of Native Starch (A), Chemically Modified Starch (B) and Enzymatic Modified Starch (C) at $10 \mu \mathrm{m}$

Enzymatically modified starch (EMS) showed that the granule surface is relatively rough, pores, cracks on surface fissures Figure 1(C). Due to a-amylase treatment, the starch granule showed many pits or pores while size remains unaltered. However, some granules with larger pits were also observed. Enzymatic treatment resulted in the weak structured granules with opened cracks and exposed pronounced layer structure. Similar observations were reported for starch digestion by a-amylase Sreenath (1992). Hydrolyzed tapioca starch contained some residual granular structure (Khatoon Sakina et al., 2009).

\subsection{Effect of modification of starch on particle nature of starch}

The native starch and modified starch were subjected to XRD analysis and obtained results are presented in Figure 2 (A, B, C). Native cassava starch had a typical B -type X-ray diffraction pattern The stronger peak of the graph is observed at $5^{\circ}$ and the higher peak is at $15.3^{\circ}$. Peaks were also observed at $17.23^{\circ}$ and $22.71^{\circ}$ in native starch.

In modified starches, XRD graph shows comparatively reduced peak and covers a larger area. This shows the reduction in crystallinity of starch structure. The X-ray diffraction pattern of the modified starches showed typical A-type starch peaks, but the relative crystallinities were lower than that of raw starch. A similar trend was recorded by Tanan et al. (2019). 

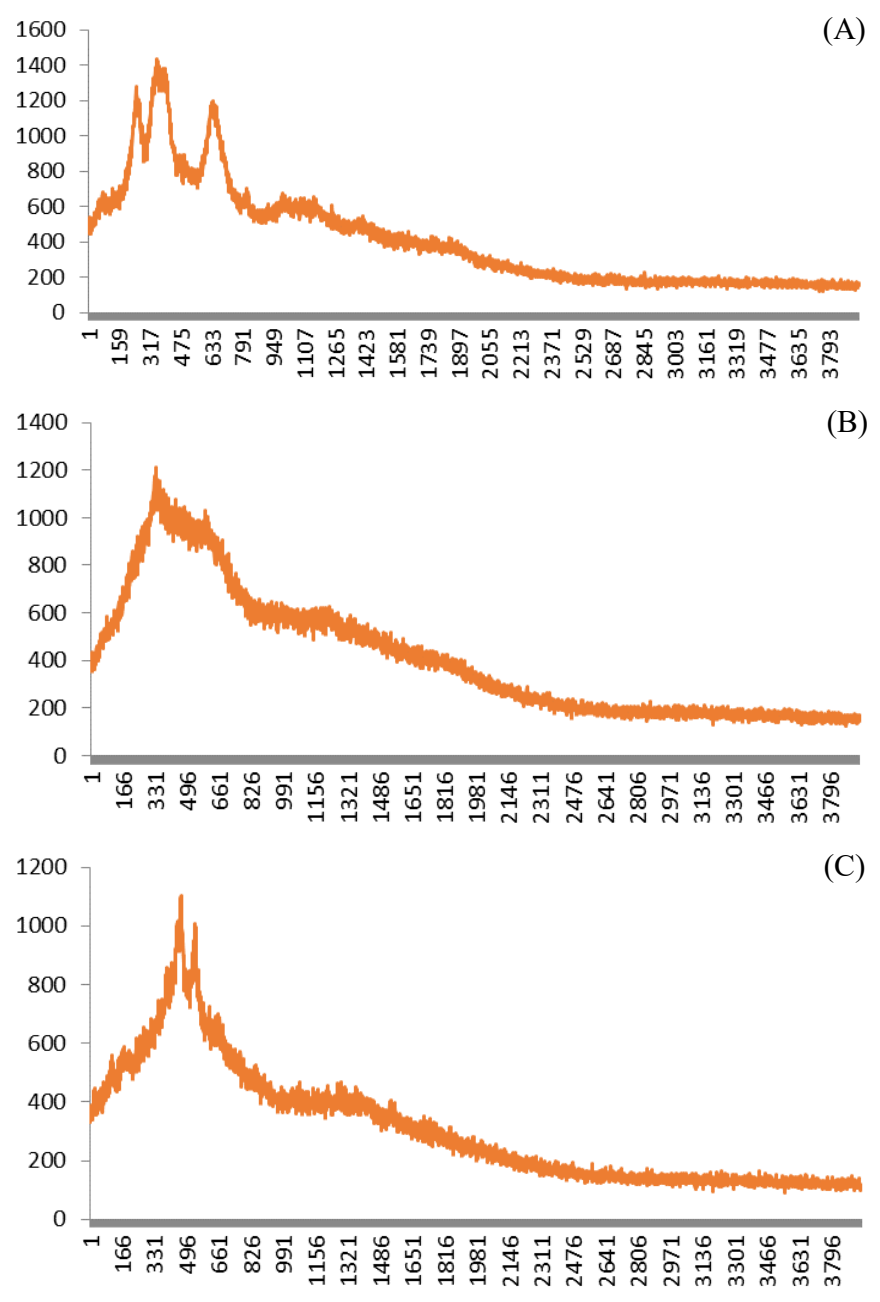

Figure 2. X- ray diffraction pattern of starch obtained from (A) cassava native starch (B) chemically modified starch (C) enzymatic modified starch

\subsection{FT-IR Image of starch and modified starch}

As per Beer's law, the amount of absorption is directly proportional to the amount of constituent present in the starch. The peak values of the NS spectrum corresponding to the absorption values. Here the peak values were determined using local maxima concept. The local maximum of a function is a value that greater than all values that are near it. The resulting spectrum represents the molecular absorption, creating a molecular fingerprint of the sample. Like a fingerprint, no two unique molecular structures produce the same infrared spectrum. This makes infrared spectroscopy useful for several types of analysis.

The mid-infrared spectrum $\left(4000-400 \mathrm{~cm}^{-1}\right)$ is approximately divided into four regions. The nature of a group frequency is determined by the region in which it is located. The regions are generalized as follows: the $\mathrm{X}-$ $\mathrm{H}$ stretching region $\left(4000-2500 \mathrm{~cm}^{-1}\right)$, the triple-bond region (2500-2000 $\left.\mathrm{cm}^{-1}\right)$, the double-bond region (2000$\left.1500 \mathrm{~cm}^{-1}\right)$ and the fingerprint region $\left(1500-600 \mathrm{~cm}^{-}\right.$ $\left.{ }^{1}\right)$. The fundamental vibrations in the $4000-2500 \mathrm{~cm}^{-1}$ region are generally due to $\mathrm{O}-\mathrm{H}$ (alcohol or carboxylic acid), $\mathrm{C}-\mathrm{H}$ (terminal alkyne) and $\mathrm{N}-\mathrm{H}$ stretching. $\mathrm{O}-\mathrm{H}$ stretching produces a broad band that occurs in the range $3700-3600 \mathrm{~cm}^{-1}$ (alcohol). From the literature review, N $-\mathrm{H}$ stretching is usually observed between 3400 and $3300 \mathrm{~cm}^{-1}$. This absorption is generally much sharper than $\mathrm{O}-\mathrm{H}$ stretching and therefore be differentiated. $\mathrm{C}-\mathrm{H}$ stretching bands from aliphatic compounds occur in the range $3000-2850 \mathrm{~cm}^{-1}$. If the $\mathrm{C}-\mathrm{H}$ bond is adjacent to a double bond or aromatic ring, the $\mathrm{C}-\mathrm{H}$ stretching wave number increases and absorbs between 3100 and 3000 $\mathrm{cm}^{-1}$ (alkene or arene) (Sacithraa et al., 2013).

The principal bands in the $2000-1500 \mathrm{~cm}^{-1}$ region are due to $\mathrm{C}=\mathrm{C}$ and $\mathrm{C}=\mathrm{O}$ stretching. Carbonyl stretching is one of the easiest absorptions to recognize in an infrared spectrum. It is usually the most intense band in the spectrum and depending on the type of $\mathrm{C}=\mathrm{O}$ bond, occurs in the $1830-1650 \mathrm{~cm}^{-1}$ region. The metal carbonyls absorb above $2000 \mathrm{~cm}^{-1} . \quad \mathrm{C}=\mathrm{C}$ (alkene) stretching is much weaker and occurs at around $1650 \mathrm{~cm}^{-}$ 1 , but this band is often absent for symmetry or dipole moment reasons. $\mathrm{C}=\mathrm{N}$ stretching also occurs in this region and is usually stronger.

\subsection{Effect of modification of starch on particle nature of starch}

As per Beer's law, the amount of absorption is directly proportional to the amount of constituent present in the starch. Figure 3 (A, B, C) of IR spectra of the native starch and modified starch showed the typical peaks for the starch backbone. However, the $\mathrm{O}-\mathrm{H}$ (alcohol) stretching band in the region $3500-3000 \mathrm{~cm}^{-1}$ was found to be broadened and became less sharp, strong and broad in the spectra of the native and chemical modified starch, in comparison to that of the enzyme modified starch. It shows the alkenes are converted into Carboxylic acids. In addition, in the IR spectra of the native starches, the characteristic absorption bands of starch at $996.23 \mathrm{~cm}^{-1}, 1076 \mathrm{~cm}^{-1}, 1148 \mathrm{~cm}^{-1}$ and $1335 \mathrm{~cm}^{-1}$ which are due to $\mathrm{C}-\mathrm{O}$ stretching vibrations, were highly diminished in intensity. In addition, in the IR spectra of the enzymatic modified starches, the characteristic absorption bands of starch at $1015 \mathrm{~cm}^{-1}, 1147 \mathrm{~cm}^{-1}$, $1642 \mathrm{~cm}^{-1}$ which are due to $\mathrm{C}-\mathrm{O}$ stretching vibrations, were highly diminished in intensity. It shows the changes in Carboxylic group. In addition, in the IR spectra of the cross-linked starches, the characteristic absorption bands of starch at $996.63 \mathrm{~cm}^{-1}, 1078 \mathrm{~cm}^{-1}, 1147 \mathrm{~cm}^{-1}, 1347 \mathrm{~cm}^{-1}$, and $1587 \mathrm{~cm}^{-1}$, which are due to $\mathrm{C}-\mathrm{O}$ stretching vibrations, were highly diminished in intensity (Sacithraa et al., 2013). 

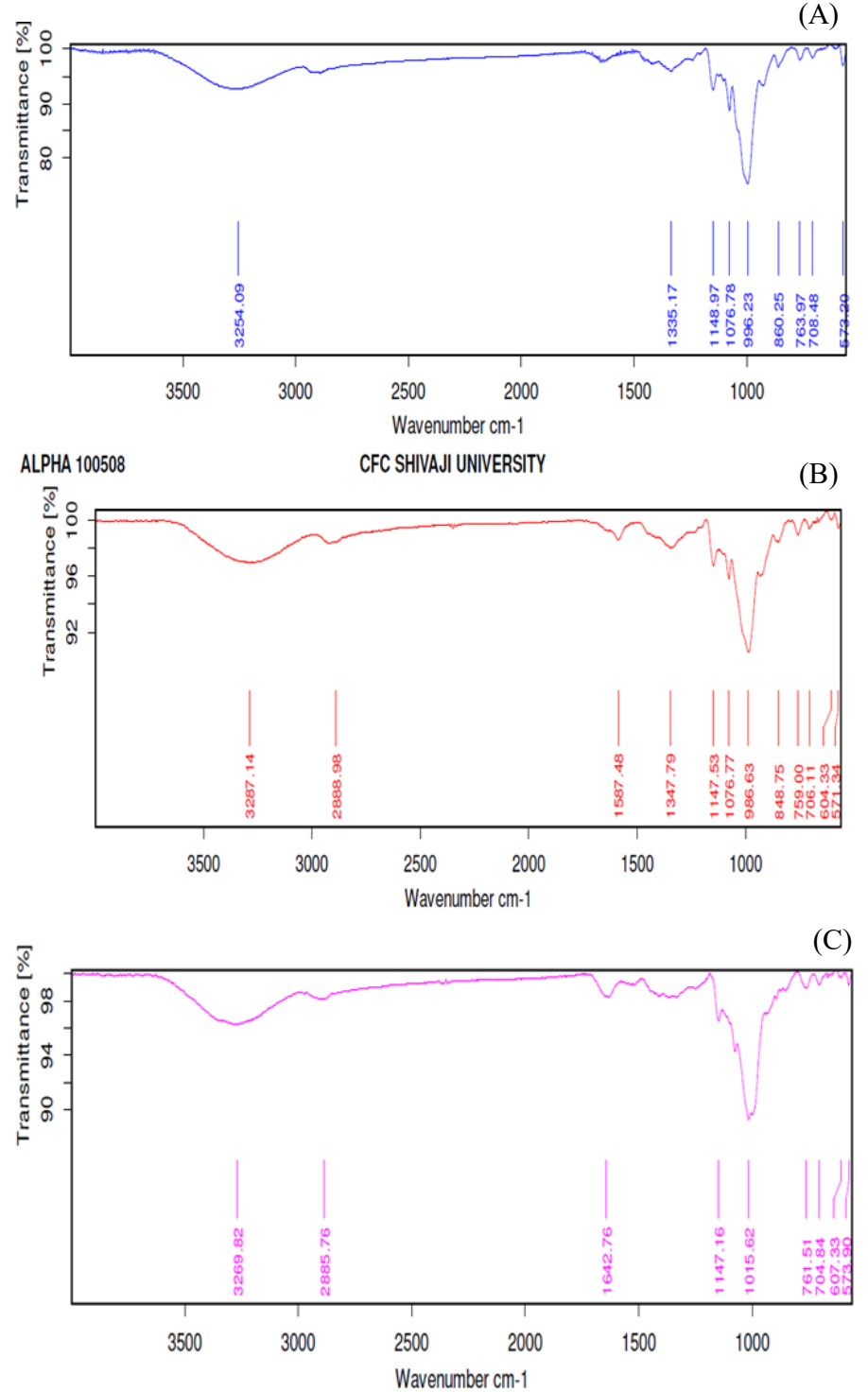

Figure 3. FT-IR spectrum of Cassava (A) Native starch (B) Chemically modified starch (C) Enzyme modified starch.

\section{Conclusion}

Proximate composition, functional properties and structural characteristics of native cassava starch and its modified forms were studied. The purpose of starch modification was to improve its functional characteristics. The low non-starch components include moisture, protein, fat-reduced after modification of starch. Modification of native starch enhances the functional properties of starch. Water-binding capacity and solubility of starch granules increased by chemical and enzymatic modification. Scanning electron micrographs revealed that the enzymatic modification imparts relatively rough surface, pores and cracks on surface fissures. The X-ray pattern of the modified starches showed comparatively reduced peak than the native starch and modifications altered the starch granules morphology to a certain extent. The properties of the modified starches studied indicate their suitability in various industrial applications such as in food products as a thickening agent, stabilizer or emulsifier; in biomedical applications as materials for bone fixation and replacements, carriers for controlled release of drugs and bioactive agents.

\section{References}

Akubor, P.I. (2007) Chemical, functional and cookies baking properties of soybean/maize flour blends. Journal of Food Science and Technology, 44(6), 619 -622 .

Anderson, R.A.B.S., Conway, H.F.B.S. and Peplinski, A.J.B.S. (1969). Gelatinization of corn grits by role and extrusion cooking. Cereal Science Today, 14 (11), 4-12.

Betancur-Ancona, D.A., Garcia-Cervesa, E., CanizaresHernandez, E. and Chel-Guerrero, L. (2002). Chemical modification of jack bean (Caravaliaensiforonis) starch by succinylation, Starch/Stärke, 54(11), 540-546. https:// doi.org/10.1002/1521-379X(200211) 54:11<540::AID-STAR540>3.0.CO;2-\#

Das, A.B., Singh, G., Singh, S. and Riar, C.S. (2010). Effect of acetylation and dual modification on physico-chemical, rheological and morphological characteristics of sweet potato starch. Carbohydrate Polymers, 80(3), 725-732. https://doi.org/10.1016/ j.carbpol.2009.12.018

Dupuy, N., Wojciechowaski, C., Ta, C.D., Huvenne, J.P. and Legrand, P. (1997). Mil-infrared spectroscopy and chemometrics in corn starch classification. Journal of Molecular Structure, 410-411, 551-554. https://doi.org/10.1016/S0022-2860(96)09517-8

French, D. (1984). Organisation of structure granules. In Whistler, R.L., BcMiller, J.M. and Paschall, E.F. (Eds.). Starch chemistry and technology. $2^{\text {nd }}$ ed., $p$. 184-247. New York: Academic Press. https:// doi.org/10.1016/B978-0-12-746270-7.50013-6

Gonzalez, Z. and Perez, E. (2002). Effect of acetylation on some properties of rice starch, Starch/Starke, 54(3 -4), 148-154. https://doi.org/10.1002/1521-379X (200204)54:3/4<148::AID-STAR148>3.0.CO;2-N

John, J.K., Raja, K.C.M., Rani, S., Moorthy, S.N. and Eliasson, A. (2002). Properties of arrow root starch treated with aqueous $\mathrm{HCl}$ at ambient temperature. Food and Chemical Toxicology, 67(1),10-14. https:// doi.org/10.1111/j.1365-2621.2002.tb11350.x

Kapelko-Zeberska, M., Zieba, T., Spychaj, R. and Gryszkin, A. (2015). Acetylated adipate of retrograded starch as RS 3/4 type resistant starch. Food Chemistry, 188(1), 365-369.https:// doi.org/10.1016/j.foodchem.2015.05.018.

Kaper, T., Talik, B., Ettema, T.J., Bos, H., Van der 
Maarel, M.J. and Dijkhuizen, L. (2005). Amylomaltase of Pyrobaculum aerophilum IM2 produces thermo reversible starch gels. Applied and Environmental Microbiology, 71(9), 5098-5106. https://doi.org/10.1128/AEM.71.9.5098-5106.2005

Kaur, M., Oberoi, D., Sogi, D. and Gill, B. (2011). Physicochemical, morphological and pasting properties of acid treated starches from different botanical sources. Journal of Food Science and Technology, 48(4), 460-465. https://doi.org/10.1007/ s13197-010-0126-x

Khatoon Sakina, A., Sreerama, N., Raghavendra, D., Suvendu, B. and Bhat, K. (2009). Properties of enzyme modified corn, rice and tapioca starches. Food Research International, 42(10), 1426-1433. https://doi.org/10.1016/j.foodres.2009.07.025

Leach, H.W., Mc Cowen, L.D. and Schoch, T.J. (1959). Structure of the starch granule. Swelling and solubility patterns of various starches. Cereal Chemistry, 36, 534-544.

Liu, H., Ramsden, L. and Corke, H. (1999). Physical properties of cross-linked and acetylated normal and waxy rice starch. Starch, 51(7), 249-252. https:// doi.org/10.1002/(SICI)1521-379X(199907) 51:7<249::AID-STAR249>3.0.CO;2-O

Mauro, D.J. (1996). An update on starch. Cereal Food World, 41, 776-780.

Miyazaki, M., Pham, H., Tomoko, M. and Naofumi, M. (2006) Recent advances in application of modified starches for bread making. Trends in Food Science and Technology, 17(11), 591-599. https:// doi.org/10.1016/j.tifs.2006.05.002

Olayinka, O.O., Adebowale, K.O. and Olu-owolabi, I.B. (2013). Physicochemical properties, morphological and X-ray pattern of chemically modified white sorghum starch. Journal of Food Science and Technology, 50(1), 70-77. https://doi.org/10.1007/ s13197-011-0233-3

Panse, V.G. and Sukhatme P.V. (1989). Statistical methods for agricultural workers. Publication and information division. New Delhi, India: Indian Council of Agricultural Research.

Rajan, A. and Emilia, A. (2006). Enzymatic modification of cassava starch by bacterial lipase. Bioprocess Biosystem Engineering, 29(1), 65-71. https:// doi.org/10.1007/s00449-006-0060-5

Ranganna, S. (1987). Handbook of analysis and quality control for fruit and vegetable products, New Delhi, India: Tata McGraw Hill.

Reddy, K. and Bhotmange, M. (2013). Isolation of starch from rice and its morphological study using scanning electron microscopy. International Journal of
Agriculture and Food Science Technology, 4(9), 859 $-866$.

Sacithraa, R., Mohan, M. and Vijayachitra, S. (2013). Quantitative Analysis of Tapioca Starch using FT-IR spectroscopy and partial least squares. International Journal of Computer Applications, 1, 29-33.

Santana, A.L. and Meireles, M.A.A. (2014). New starches are the trend for industry applications: A review. Food and Public Health, 4(5), 229-241. https://doi.org/10.5923/j.fph.20140405.04

Sathe, S.K., Iyer, V. and Salunkhe, D.K. (1981). Investigations of the Great Northern Bean (Phaseolus vulgaris L.) Starch: Solubility, Swelling, Interaction with Free Fatty Acids, and Alkaline Water Retention Capacity of Blends with Wheat Flours. Journal of Food Science, 46(6), 1914-1917. https://doi.org/10.1111/j.1365-2621.1981.tb04518.x

Singh, J., Kaur, L. and McCarthy, O. (2007). Factors influencing the physic chemical, morphological, thermal and rheological properties of some chemically modified starches for food applications. Food Hydrology, 21(1), 1-22. https:// doi.org/10.1016/j.foodhyd.2006.02.006

Sreenath, H. (1992). Studies on starch granules digestion by $\alpha$-amylase. Starch/Starke, 44(2), 61-63. https:// doi.org/10.1002/star.19920440208

Tanan, W., Panichpakdee, J. and Saengsuwan, S. (2019). Novel biodegradable hydrogel based on natural polymers: Synthesis, characterization, swelling/ reswelling and biodegradability. European Polymer Journal, 112, 678-687.

Tester, R. F., Karkalas, J. and Qi, X. (2004). Starchcomposition, fine structure and architecture. Journal of Cereal Science, 39(2), 151-165. https:// doi.org/10.1016/j.jcs.2003.12.001

Wootton, M. and Chaudhry, A. (1979). Enzymatic digestibility of modified starches. Starch/Starke, 31 (7), 224-228. https://doi.org/10.1016/ j.eurpolymj.2018.10.033

Zhong, Q.P. and Xia, W.S. (2008). Physicochemical properties of chitosan-based films. Food Technology and Biotechnology, 46(3), 262-269. 